\title{
Linking Corporate Social Responsibility in Sport with Community Development: An Added Source of Community Value
}

\author{
Sylvia Trendafilova, Vassilios Ziakas \& Emily Sparvero
}

Published in: Sport in Society

\begin{abstract}
This paper investigates the attributes of Corporate Social Responsibility programs in sport and their potential for sustainable community development. The gap between sport-related CSR and community development needs be filled by shifting attention to the capacity-building of communities. While the neo-liberal foundations of CSR are recognized, it is essential to understand the ideological varieties driving CSR that can enable inclusiveness and collaboration in fostering community benefits of CSR programs. The paper contributes to the literature on CSR in sport advancing the discourse, and sets the stage for a community-based framework for research: (1) related to sport as a tool for social change; (2) exploring the relationship of organizational motives, stakeholder engagement and CSR program design/implementation; and (3) evaluating the perceived benefits of CSR programs, and the extent to which these can help achieve sustainable community development.
\end{abstract}

Keywords: Corporate social responsibility, sport-for-development, community, sport, development. 


\section{Introduction}

Society increasingly looks to business entities to address various social issues, such as education, poverty, and the environment. This is due to the mutual dependencies between society and business, as well as decreased funding for social programs consistent with the current neoliberal philosophy of many local and national governments. This, in turn, has put pressure on companies to adopt socially responsible programs and incorporate them into their traditional business model. Falling under the umbrella of Corporate Social Responsibility (CSR), actions and programs to resolve these problems are defined by the voluntary integration of social and environmental concerns into a business's practices (Prieto-Carron, Lund-Thomsen, Chan, Muro, \& Bhushan, 2006). Based on this view, the organization is considered a social entity and part of society with benefits and obligations.

While CSR has received a great deal of attention in the management literature since Carroll's foundational work, there is no consensus on how to best understand and operationalize CSR. There are multiple definitions, as well as a number of models, that attempt to depict the concept of CSR and the processes involved in the adoption of CSR practices among corporations (Carroll, 1979, 1991; Subhabrata, 2007; Waddock, 2004). For example, CSR has been defined as a company's commitment to minimizing or eliminating its harmful effects on society and maximizing its long-term beneficial impact (Mohr, Webb, \& Harris, 2001). Such commitment and actions are not necessarily required by law (McWilliams \& Siegel, 2000). In addition, those practices aim to "improve the workplace and benefit society in ways that go above and beyond what companies are legally required to do" (Vogel, 2005, p. 2). In other words, CSR is the commitment of an organization to improve community well-being through the adoption of appropriate business practices and through contributions of corporate resources. CSR has also 
been viewed as a way to manage and respond to societal and stakeholder demands (Crampton \& Patten, 2008). In his analysis of 37 different definitions, Dahlsrud (2008) points out that various CSR definitions are describing a phenomenon, but fails to present a description of how to manage the challenges within this phenomenon. The challenge of developing a single and unbiased definition is compounded by the view of CSR as a social construction. Additionally, different stakeholders may interpret CSR differently, and the concept "overlaps with other business and society concepts, most notably stakeholder theory and corporate citizenship" (Walters \& Anagnostopoulos, 2012, p.417).

Although research on CSR in the realm of sport is relatively new, attempts to define CSR in sport have been made as well. For example, Kotler and Lee (2005) defined CSR as the discretionary business practices committed to improve the well-being of the community, and believe these practices should be completely voluntary. More recently, Walker and Parent (2010), have proposed an integrated framework of corporate social responsibility, responsiveness, and citizenship in sport by adopting Frederick's $(1986 ; 1994)$ labels of CSR.

As a significant sector in the world economy, with its own broadcasting rights, merchandising, and sponsorship agreements, the sport industry has recognized the importance of CSR programs (Breitbarth \& Harris, 2008). For example, major league professional sport in North America has increasingly emphasized the important role of CSR as part of the business model (Babiak \& Wolfe, 2006, 2009; Babiak \& Trendafilova, 2011; Brietbarth \& Harris, 2008; Sheth \& Babiak, 2010; Smith \& Westerbeek, 2007; Walker \& Kent, 2009). Because of their strong connection to the community and importance of stakeholder relationships, professional sport clubs in Europe are also showing a growing interest in CSR activities (Hamil \& Morrow, 2011). The Asian region is not that far behind, with Japan playing a significant role in the 
shaping of the CSR discussion in the field of sport by adopting initiatives that range from visits to welfare facilities and hospitals to environmental cleaning campaigns (Breitbarth \& Harris, 2008). This movement illustrates the growing importance of CSR in the sport industry worldwide.

Despite the growing interest in sport-related CSR, the current discourse focuses primarily on examining the socially responsible behavior of individual organizations and the implementation of CSR programs. Sport entities such as leagues, clubs, major events and nonprofit organizations are embedded within local communities and a broader nexus of stakeholder relationships that impact society at large. Although this is a fundamental tenet of CSR, it is surprising that local communities are predominantly viewed as passive beneficiaries. A community-centered perspective aligned with the pillars of sustainable development can shift the focus (and shared responsibility) on the impacted communities to facilitate the attainment of benefits from CSR programs implemented by sport organizations. While sustainable development is commonly used to reference the natural environment, in this paper, it adopts a broader view by including all aspects of community development. Thus, the community-centered perspective requires collaboration between sport organizations and community development entities aimed at fostering, spreading and sustaining the value of CSR programs to the affected communities. Such collaboration can be achieved if sport-related CSR is theoretically and practically connected with the emerging field of sport-for-development that examines the strategic use of sport as a vehicle to achieve positive social change and sustainable development.

In this regard, this paper proffers that the CSR programs of sport organizations can be explicitly linked to the community development agenda, including the triple-bottom line of economic, social, and environmental development (Sheth \& Babiak, 2010), and the associated 
development policies of impacted communities and/or countries. Rather than viewing CSR programs in isolation, countries/local authorities can take action in cooperation with sport organizations to increase the value of such programs by implementing joint strategies. For example, the National Football League has implemented Play 60, a multi-pronged CSR program focused on reducing childhood obesity. At the league level, the program has engaged nationallyelected officials, including the President of the United States and the First Lady, in promotional and lobbying efforts. Play 60 activities are also implemented on a local level by individual NFL franchises, who partner with local schools to promote physical activity. Although Play 60 is only one example, it demonstrates the potential for broad community engagement in support of CSR programs. Most importantly, this coincides with the evidently evolving character of business and CSR that have taken a political role (Scherer \& Palazzo, 2011), and by extension can enable the use of sport-related CSR as a policy tool for social change. Based on these premises, the paper has a twofold purpose: to review CSR and sport-related literature and to provide a case for a broader conceptualization of CSR that incorporates sustainable community development.

\section{Corporate Social Responsibility: Strategy and Community Development}

Carroll's (1991) CSR pyramid is the most well-known model of CSR, with its four levels indicating the relative importance of economic, legal, ethical and philanthropic responsibilities corporations have. Over the past 26 years Carroll's model has been a leading paradigm and frequently adopted in top management and CSR journals. His overview of the evolution of CSR not only provided an in-depth historical outline of the concept but predicted that the future of CSR would revolve around measurement initiatives as well as theoretical developments (Carroll, 1999). Similarly, Cochran (2007) provided an overview of how the focus of the CSR debate has 
changed over the years from a narrow to a multifaceted one, concluding that "perhaps the most important intellectual breakthrough regarding modern conceptions of CSR is that socially responsible activities can, and should, be used to enhance the bottom line" (p.453).

The increasing importance of CSR is reflected in the growing attention this topic has received in the academic literature (Campbell, 2007; Gouldson, 2006; Margolis \& Walsh, 2003; Orlitzky, Schmidt, \& Rynes, 2003; Siegele \& Ward, 2007). The focus of much of the scholarship has been on the strategic nature of CSR activities and how external pressure shapes those activities, echoing a neo-liberal mindset (Hess, Rogovsky, \& Dunfee, 2002; Hess \& Warren, 2008; Marquis, Glynn, \& Davis, 2007) rather than welfare state policies. Neo-liberalism is most commonly associated with the market-oriented philosophy and global capitalism that promotes deregulation, privatization as well as the free movement of trade and capital, which is exemplified by the work of institutions such as the World Trade Organization (WTO), the International Monetary Fund (IMF), and the World Bank (Boas \& Ganse-Morse, 2009; Harvey, 2005; Peck, 2010). Accordingly, Belliveau, Cottrill, and O'Neill (1994) proposed a model that predicts an organization's social responsiveness based on external factors such as institutional variables (e.g., CSR behavior in the industry), economic variables (e.g., level of concentration, market share), and managerial variables (e.g., innovation). Porter and Kramer (2006) advocate a strategic approach to managing CSR for ultimate reward, by mapping the social impact of its various value chain activities to identify opportunities for the firm to reduce the negative ones and find positive openings to achieve social and strategic distinction. Bonini et al. (2006) suggest that CSR awareness should be incorporated into core strategic decision making processes to forestall long-term financial and reputation risks. The key is that CSR should be viewed as a strategic investment, and the scope of activities associated with CSR need to be expanded in 
order to achieve strategic advantage. Such an expansion of economic, social and environmental initiatives can potentially enable the incorporation of CSR into sustainable community development strategies.

Although many scholars classify prima facie a strategic CSR approach in the realm of neo-liberalism, or at least substantially driven by a neo-liberal logic that serves primarily corporate interests (Banerjee, 2007; Hanlon, 2008; Kinderman, 2011; Reich, 2007; Shamir, 2008), it is imperative to broaden this interpretation if it is to include a community-based perspective. This is because the dominance of a neo-liberal approach to CSR may preclude essentially a community-driven (as opposed to corporate-led) agenda that embraces and exploits CSR initiatives for its own purposes aligned with sustainable development. Thus, the hegemony of neo-liberalism in CSR discourse can strip its positive and transformative social value with the result of turning away civic-minded community development actors who support the welfare state.

Vallentin (2012) suggested a more nuanced understanding of the relationship between neo-liberalism and CSR, challenging stereotypical depictions of CSR as a neoliberal discourse and arguing that there is a need for greater awareness of the varieties of liberalism at play in CSR. Viewed through this prism, although CSR is recognized as a liberal conception, its political meaning is not contained within neo-liberalism. Vallentin, in providing a pluralist account of neo-liberalism and its ideological entanglements in CSR, pointed to the contextual embeddedness of CSR government actions maintaining that there is no pure neo-liberal governmentality. Instead, it is always linked to other modes of power, government and social technology (Hilgers, 2010), thus creating 'hybrid' institutional landscapes of 'actually existing 
neo-liberalism' in which commodifying and market-constraining logics commingle and coevolve (Brenner, Peck, \& Theodore, 2010).

This pluralist - and more encompassing - foundation of strategic CSR as a hybrid mode of 'actually existing neo-liberalism' opens up possibilities for envisioning the conditions that can enable its incorporation into sustainable community development strategies. It does so, by widening the ideological scope of CSR policy discourse and its expected impacts on the community level based on the contextual embeddedness of CSR programs in terms of how they interact with other policies, systems and ways of thinking about and acting upon CSR. From this standpoint, an inclusive range of stakeholders can be potentially engaged in the processes of CSR program design and implementation, which is essential for community development. In this vein, CSR can also turn out to be a lever for continuous development inside corporations and thus help to further the cause of sustainable development (Vallentin, 2012).

The rapidly increasing attention to CSR in sport provides an embedded hybrid context wherein strategy-making is shaped by multiple stakeholders nested within institutions, systems and relationships. The significance of sport as a tool for community development and as a vehicle for deploying CSR programs is based on its unique features: 1) mass media distribution and communication power; 2) youth appeal; 3) medium for delivering positive health impacts; 4) social interaction; 5) cultural integration; 6) promote environmental and sustainability awareness; and 7) provide immediate gratification (Smith \& Westerbeek, 2007). Other scholars have also emphasized the distinct characteristics of sport (passion, economics, transparency, and stakeholder management) and have pointed out that sport provides a unique setting for CSR activities (Babiak \& Wolfe, 2013). These unique characteristics make sport an attractive platform 
for social change by improving quality of life, reducing conflict between communities and nations, and fostering sport development (Hayhurst, 2009).

Misener and Mason (2009) addressed the relationship between sport-related CSR and community development, by interpreting the concept of CSR as community development initiatives, in their analysis of sporting events strategies in three comparable sport-friendly cities in Canada, United Kingdom and Australia. They also defined community development holistically as "building active and sustainable local communities based on social justice and mutual respect, and changing power structures to remove the barriers that prevent people from participating in the issues that affect their lives." (p. 773). This assessment of community development initiatives related to sport revealed that influential stakeholders acknowledged that the strategic use of sport events was uniquely tied to communities and community development goals albeit with varying perceptions of impact. The recognition of CSR as a community development platform pinpoints the importance of local context and geographical focus of CSR initiatives (Kulczycki \& Koenigstorfer, 2016; Walker \& Parent, 2010), which needs to be systematically examined. It is also important to explore the manifestations of CSR in different countries worldwide, which have different sport systems and traditions. Such knowledge could help us develop an understanding of the conditions and means that foster the value of CSR programs for local communities. Furthermore, investigations of multicultural sport organizations with existing CSR activities would contribute to the development of a framework that explains "not only social responsibility in sport but also social responsibility via sport obligations" (Banda \& Gultresa, 2015, p. 200).

In parallel with the increasing attention to CSR in sport, there has also been increasing political and institutional support for sport-based projects aimed at contributing to positive 
community development outcomes in areas including economic development, social inclusion, cultural cohesion, healthy lifestyles, education, gender equity, and reconciliation and peacebuilding (Levermore \& Beacom, 2009; Schulenkorf \& Adair, 2014; Sherry, Schulenkorf \& Chalip, 2015). This has led to the substantial growth of the sport-for-development field. Levermore (2010) addresses the potential benefits and limitations associated with deploying CSR activities for development, indicating that CSR development initiatives through sport could extend to communities where traditional development strategies tend to be challenging. As Sherry, Schulenkorf and Chalip (2015) observe, the popularity of sport-for-development stems from its ability to capture or "hook" a variety of people, particularly those interested in sport and physical activity, and use the momentum in and around sport as a strategic vehicle to achieve non-sport development goals. Yet, Coalter (2013) warns that sport is not a panacea for resolving all problems of the world and a more careful, evidence-based approach on implementing sportfor-development projects is needed. Indeed, the field of sport-for-development is moving towards this direction starting to critically account for the intricacies and challenges involved in strategically employing sport as a lever for social change and development under neo-liberalist agendas (Lyras \& Welty Peachey, 2011; Schulenkorf, 2012; Skinner, Zakus, \& Cowell, 2008). As a result, the area of sport for social change has emerged as a sub-field of sport-fordevelopment that uses sport as a catalyst to build social capacity and develop socially and physically healthy communities (Sherry, Schulenkorf \& Chalip, 2015), emphasizing the need for wider community participation and empowerment in such initiatives.

However, to date there has been no effort to integrate sport-for-development and sportrelated CSR. Rather, the two fields currently operate and evolve on their own, while in many cases have identical or similar objectives. We argue that a re-conceptualization and broadening 
of our understanding of CSR in sport as an embedded hybrid context of emergent strategymaking can profitably connect it with the agenda and scope of sport-for-development to achieve sustainable community development. As such, a more comprehensive perspective can be developed of the multiple levels, contexts and relationships that exist in CSR and sport, with the potential to enable beneficial synergies for sustainable community development.

\section{Corporate Social Responsibility in Sport as a Hybrid Context of Strategy-Making}

There is a burgeoning body of CSR research, and the scholarship in the realm of sport is contributing to this body of knowledge (c.f.,Babiak \& Trendafilova, 2010; Kihl, \& Tainsky, 2013; Kulczycki \& Koenigstorfer, 2016; Walker \& Parent, 2010). Some scholars argue that the nature and role CSR plays in a sport organization may be different than in other industries because of the unique context in which sport operates (Babiak \& Wolfe, 2006, 2009; Walker \& Kent, 2009). Similarly, Smith and Westerbeek (2007) argue that sport's unique factors may positively affect the nature and scope of CSR efforts. Additionally, professional sport organizations face pressure from their host communities to establish themselves as good neighbors. These teams depend on local fans for financial success in the form of ticket and merchandise sales. Therefore, it can be to their financial benefit to engage in strategic CSR. In some cases, there is also a quid pro quo, by which the team and athletes are contractually bound to participate in activities and programs that can be considered part of a CSR portfolio in order to receive financial support for stadium projects. For example, the NFL's Dallas Cowboys received \$325 million in public funding from the team's host city, Arlington, Texas. As part of its agreement with the city, the team agreed to pay $\$ 16.5$ million "to support and benefit the youth 
of [Arlington] for sports, recreational, and educational purposes" (Charitable Contribution, 2005).

In addition to professional sport, it is important to note that National Collegiate Athletic Association (NCAA) schools' athletic departments are also integrating the environment into their planning process (Pfahl, 2010, 2011). Environmental efforts are undertaken as part of a strategic effort involving collaborative processes across university units. Athletic departments are high profile members of the communities they are located in, and the expectation is that they would join other campus units to address university environmental goals and objectives (Pfahl, Casper, Trendafilova, McCullough, \& Nguyen, 2015). Athletics is also a platform for marketing and community goodwill efforts, thus driving athletics department personnel toward addressing environmental efforts internally and through collaborative efforts (Casper et al., 2012; Pfahl \& Ott, 2010). With strategic emphasis on environmental actions, athletic departments can generate additional revenue and connect more closely with the local community (Trendafilova \& Nguyen, 2015). In turn, this close relationship could lead to the development of new partnerships and to the attraction of new donors and sponsors, thus benefiting all, the school, the athletic department and the community.

Despite the fact that sport teams have been involved in their local communities for decades, we know little about the relevance, importance, and impact of socially responsible practices to the organizations themselves, to the individuals they intend to benefit, and to the league governing bodies (Babiak \& Trendafilova, 2010). CSR initiatives in professional sport are becoming increasingly institutionalized, formalized, and strategic (Babiak \& Trendafilova, 2011; Babiak \& Wolfe, 2009). Major leagues in North America have increased the number of charitable foundations associated with the teams within the leagues (Babiak, 2010; Babiak \& 
Wolfe, 2009; Sparvero \& Kent, 2014). Similarly, elite soccer clubs in Europe have community outreach foundations with the purpose of overseeing the delivery of socially responsible initiatives (Business in the Community, 2008).

These initiatives often generate favorable benefits to the organization, such as improved brand image, increased fan loyalty, and increased sales of tickets and merchandise (Sports Philanthropy Project, 2007; Walker \& Kent, 2009). Furthermore, Babiak and Trendafilova (2011) found that institutional pressures are playing a role in the diffusion and adoption of CSR activities in major league professional sport in North America. More specifically, the following three institutional forces are relevant in influencing CSR: (1) the scrutiny / monitoring / regulation of a corporation's behavior; (2) the perception of shifts in normative standards of stakeholders, and (3) the interaction and collaboration between organizations in this sector.

There is increasing pressure in sport to adopt CSR activities and programs. Although long-term benefits have not been clearly identified, there is the potential for such programs to not only give back to the community, but also to enhance the public image of sport organizations. Consequently, there is interest in continuing existing programs and expanding the scope of CSR activities. Some of the existing programs demonstrating social responsibility are focused on environmental sustainability (Babiak \& Trendafilova, 2011), others on the specific strategic benefits such programs bring to the organization (Sheth \& Babiak, 2010). Such CSR activities could be expressed through grants, gifts, cause marketing, sponsorships, financial contributions, and/or employee volunteering and marketing (Smith \&Westerbeek, 2007).

Academic research on CSR in sport has begun to examine the discrete benefits that philanthropy, community outreach, cause marketing, employee volunteer programs and other socially beneficial activities have on the organization and its constituents (Babiak \& Wolfe, 
2006, 2009; Walker \& Kent, 2009). Focusing on the charitable side of these activities (and not so much on the profit side), scholars have studied athletes and their charitable foundations. For example, Babiak and colleagues (2012) discovered key attitudes toward philanthropy such as altruism and self-interest, emphasizing how charitable and philanthropic activities extend beyond monetary contributions. Furthermore, Ratten and Babiak (2010) elaborated on the connection between social responsibility and philanthropic endeavors, pointing out that sport teams may have an opportunity through philanthropic activities to increase their social standing in their communities. An example of such activities could be an athlete helping children become more involved in sport, thus enhancing not only the image of the athlete but the image of the team as well. The result is that being viewed as charitable helps both the athlete and the team create a positive image and gain support from key stakeholders in the community.

A growing number of professional teams and leagues in North America have demonstrated high commitment to CSR by investing substantial organizational resources into developing different programs (Babiak \& Trendafilova, 2011). Similarly, professional sport clubs in Europe have adopted CSR programs as a means to achieving strategic organizational goals (Brietbarth \& Harris, 2008). Enhanced communication of CSR activities allows for an opportunity to improve stakeholder accountability and to facilitate the development of relational partnerships and networks (Hamil \& Morrow, 2011). The European club system is traditionally community-driven (Brown, 2000), which helps foster socially-responsible efforts.

In this context, several scholars have explored the topic of partnerships by distinguishing the leveraging potential of CSR through sport. For example, Dowling and colleagues (2013) used the London 2012 Olympics to illustrate how corporations leveraged CSR, concluding that "relationships in sport can be innovative and creative but require objective alignment, 
appropriate timing and the management of expectations" (p. 269). Similarly, Walters and Anagnostopoulos (2012) examined how CSR is implemented through social partnerships. They developed a conceptual model of the process of implementation based on the social responsibility partnership programme at the Union of European Football Associations (UEFA). The conceptual model identifies three stages of the implementation process (selection, design, management), with partnership evaluation being an ongoing process during all three stages. The latter consists of two elements, namely project and process evaluation. This conceptual model contributes towards building a knowledge base on the implementation process of social partnerships and CSR.

Related to the role of partnerships in CSR programs, Kihl and Tainsky (2013) provided an example of a large scale CSR initiative (Major League Baseball's Reviving Baseball in Inner Cities) through which the MLB addresses social issues as part of a broader movement of corporate community involvement. These scholars emphasized that a key to the success of such large scale community initiatives is creating partnerships in which responsibilities are clearly defined. The salience of social partnerships in fostering the value of CSR programs is instrumental for sustainable development. The formation and implementation of such partnerships is related to the attributes and types of CSR programs that can be linked to community development. An analysis of the variety of CSR programs in different countries and sporting contexts can reveal effective CSR attributes/types.

\section{Attributes of CSR Programs Related to Sustainable Development}

Environmental sustainability represents one area of community development which has been the focus of many sport organizations around the world as they endeavor to implement CSR 
programs. The scope ranges from professional sport leagues/teams to collegiate athletics to sport events. For example, in the United States a growing number of programs have been adopted by professional sport teams (Babiak, 2010; Sparvero \& Kent, 2014; Sheth \& Babiak, 2010). Key achievements include such outcomes as having all league commissioners publicly committing to environmental stewardship, all major concessionaires developing environmentally preferable menus, and all leagues actively involved in educating their fans. At the forefront of these efforts are the Green Sports Alliance (with members representing more than 300 sports teams and venues from 20 different sports leagues and 14 countries) and the Natural Resources Defense Council (an international nonprofit environmental organization with more than 2 million members). Both organizations have worked together to establish the Greening Advisors, a guide suggesting environmentally friendly practices to green athletics and recreation. Utilizing this guide, professional sports, collegiate sports and other sport entities are actively working to promote energy efficiency, waste reduction, and water conservation just to name a few areas. These efforts have led to programs that are used to implement systems, structures and processes by which to engage in greening activities. A team at the leading end of these efforts is the Philadelphia Eagles of the National Football League (NFL), with their owner at the forefront of the adoption and implementation of environmental programs. Their stadium is the first in the United States capable of generating 100 percent of its energy from renewable sources: solar panels, biodiesel/ natural gas generator and 14 wind turbines (NRDC, 2012).

Similar activities related to environmental sustainability exist in the European sport world with programs addressing a variety of issues, including waste and litter, transport, energy efficiency, and water management. For example, Olympique de Marseille has initiated an ecocitizen program (through the club's Endowment Fund Attitude) to educate fans on issues related 
to the environment and sustainable development. Sustainability is also one of the key CSR areas for Real Madrid, with the club's strategy aiming at addressing three main issues: natural resources, biodiversity loss, and climate change. The club has adopted a vision of becoming one of the most sustainable football clubs in Europe.

While professional sports have been the main high-profile drivers behind the inclusion of sustainability on the CSR agenda, National Collegiate Athletic Association (NCAA) schools' athletic departments are also integrating sustainability into their planning process in order to most efficiently utilize scarce resources and to address the negative impact sport events and facilities have on the environment (Pfahl, 2010, 2011; Trendafilova, Pfahl, \& Casper, 2013). Athletics department personnel are beginning to examine their role in campus sustainability activities, the illustration of which is the American College and University Presidents' Climate Commitment (ACUPCC) (Swearingen White, 2009). This area of sport combines internal initiatives within athletics departments with the need to work with broader university requirements such as those of the ACUPCC. For example, many NCAA schools are following in the footsteps of the University of Colorado, the first Football Bowl Subdivision (FBS) school to launch a zerowaste program for waste reduction at football games. The program also addresses energy used in powering the stadium, team travel, and other football-related activities. Another example is North Carolina State University which has formed the Sustainability in Athletics Committee, including key university and athletic department personnel, campus sustainability office personnel, and faculty members. The committee incorporates sustainability as part of the university-wide strategic plan.

In the area of sport events, sustainability efforts have been made as well. With the International Olympic Committee (IOC) officially committing to address the natural 
environment as a social responsibility, the Vancouver and London Organizing Committees for the Olympic Games adopted holistic approaches (social, economic, and environment) to managing the events. Both organizing committees developed a sustainability policy, which included a reporting system in Vancouver (Coady et. al., 2007) and sustainability legacy in London (London 2012's sustainability legacy lives on, 2012). These developments can be traced back to the Winter Olympics at Nagano, Japan, in 1998, which marked the first Games at which the IOC had a clearly articulated environmental protection policy that was to be followed by the organizing committee (Cantelon \& Letters, 2000). The historical roots for the development of this policy were the result of the widespread environmental damage at the 1992 Albertville and the Savoie Region Games, and the subsequent environmentally conscious Green Games of Lillehammer, Norway (1994), which demonstrates the primacy of local initiatives upon transnational global concerns (Cantelon \& Letters, 2000).

In addition to environmentally-focused programs, elite soccer clubs in Europe are engaged in community development activities that address social and economic issues. Many regeneration activities focus not only on the refurbishment of the club's stadia, but also on the associated planning for area revitalization of the local community. This broad scope of CSR activities illustrates the call for viewing CSR as a strategic investment (Kramer, 2006). In return, this strategic approach to CSR has the potential to enable sustainable community development. For example, Liverpool FC worked with the community to regenerate the Amfield area. This included the construction of a new stadium while the club also restored Stanley Park (Liverpool's most historic park) by working with city council and local community. The club also worked with the Board, Liverpool City Council, and the Amfield Youth Club (AYC) to secure funding to improve and extend the former AYC buildings on Breckside Park where sports 
and other activities could continue to take place. Similar to the major professional leagues in the United States, these soccer clubs have established foundations that organize and promote CSR efforts and programs. Barcelona's foundation is the most notable example, and its foundation undertakes and promotes a wide range of CSR programs that have at their core the Catalan culture and identity. This focus on the local community and traditions has the potential to increase the social standing of the club (Ratten \& Babiak, 2010), and strengthen social partnerships. Such partnerships have the power to foster the value of CSR programs and to promote community development (Walters \& Anagnostopoulos, 2012). Lastly, the creation of a separate foundation may allow for more efficient delivery of CSR programs, allowing the team and the team management to focus on club performance and operations, while the foundation staff and board of directors are dedicated to CSR.

However, little research has specifically addressed how CSR is employed in conjunction with events for social development, and subsequently, little is known about how host cities develop and undertake CSR initiatives (Carey, Mason, \& Misener, 2011). In addressing this gap, Carey et al. (2011) examined the 2016 Summer Olympic Games bids to determine how the focus on CSR and community development differs in traditional versus non-traditional bid cities. They found that the discourse surrounding the Rio de Janeiro bid put a greater focus on the capability of sport to reach out to disadvantaged populations and create balance within the global economy. Other scholars utilized a case study of the 2010 Vancouver Winter Olympics and Paralympic Games to illustrate how sustainable development was adopted as a means of social responsibility and corporate community involvement in the Games (Misener, Sant, \& Mason, 2013). The efforts associated with socially responsible development attracted corporations seeking to invest in sustainable development programming. 
Staging the Olympics requires a substantial urban development, which has ultimately evolved the Games into a tool for urban renewal and a catalyst for regional development (Essex \& Chalkley, 2003). With the construction of sport facilities along with all other infrastructure development (e.g., transportation, accommodations), the Games have the potential to facilitate the long-term development of tourism (Chalip, 2002). Furthermore, such development and improved urban environment can promote future business investments. Future research should examine who is driving the process of bidding and how this influences the social responsibility schemes included within those bids. An attempt should be made to determine if CSR and social development is actually an integral part of the overall bid process or it is merely driven by corporations who are attempting to utilize the value and altruistic nature of sport to fulfil their own goals (Carey et al., 2011). Scholars have also explored how CSR is leveraged through sport by organizations in the lead up to mega sporting events (Dowling, Robinson, Washington, 2013). The authors concluded that CSR relationships in sport can be innovative and creative but require objective alignment, appropriate timing and the management of expectations.

To sum up, sport is emerging as a unique platform for CSR (Coady et al., 2007). Sport entities are incorporating corporate partnerships into their CSR programs; hoping to generate favorable brand imaging, fan loyalty, ticket sales, and sport development (Sports Philanthropy Project, 2007), with these efforts becoming increasingly institutionalized and formalized (Babiak \& Trendafilova, 2011; Babiak \& Wolfe, 2006). However, the challenges of incorporating them into the local community development in a holistic manner remain, with the main challenge being that sustainability efforts are in their infancy or are still managed in an ad hoc manner. If developed and implemented in a strategic manner, CSR community focused programs have the potential to create a positive social impact, leading to a sustainable development. In turn, CSR 
programs focused on sustainable development could benefit both the sport organization and society as a whole.

Sport organizations often operate teams, venues, and events that are resource-intensive (Babiak \& Trendafilova, 2011). Thus, strategies to reduce the social, environmental, and financial costs could potentially create a number of attractive outcomes for the sport organization as well as its local and global community. CSR sustainability programs are perceived as valuedriven with many benefits that are not reflected in traditional financial terms (Babiak \& Trendafilova, 2011). Considering the shifting social consciousness around development issues and the social bonds or contracts sport organizations have with local communities, sport organizations have the potential to take advantage of these opportunities in taking the lead in making sustainable community development a CSR priority.

\section{Moving Forward: A Community Development Research Agenda for CSR in Sport}

CSR activities are context-dependent and ever-evolving, based on community needs and resource availability. Organizations need to recognize the dynamic nature of CSR and should incorporate evaluation into the strategic management of such initiatives in order to address this evolution. If organizations fail to adopt this view, the full scope of benefits will not be realized. Additionally, we believe that the scope of CSR programs is broad and should be further explored in relation to its potential for contributing to sustainable community development. For example, CSR programs among the European sport clubs play a multifaceted role and reflect the European tradition of the close relationship between the community and the sport club. Although this varies from one country to another according to national sport policy and governance structures (Henry, 2009), an EU sports policy has developed after the European Court of Justice rulings, 
defining sports as an economic business, and subsequently the Commission embarked on negotiations with sport stakeholders to reach mutually satisfying agreements before any cases might be brought before courts (Croci, 2009). This illustrates the sport governance transformation within EU towards more horizontal configurations of stakeholder networks (Garcia, 2009), pushing sport organizations to address a range of social issues in response to community concerns and problems. However, the multiplicity of goals raises the question of how effective CSR programs are in addressing a wide array of goals. Sport organizations have limited resources and the first priority of most sport organizations is the bottom line.

There is also a need to explore and study integrated CSR programs (i.e., CSR programs that reflect the community character and embeddedness of sport) in more depth. As ParamioSalcines, Babiak and Walters (2013) suggest in the concluding remarks of their book, CSR initiatives need to be embedded within the organization through strategy, policies and processes, which has the potential to lead to a socially responsible behavior that is the norm across organizations. The focus needs to shift from CSR benefits to the organization to the benefits to stakeholders by considering the viewpoints of multiple stakeholders.

Sport organizations have been running community-oriented programs for several years; hence they consider themselves as part of the social fabric of their local communities (Business in the Community, 2008). By understanding the foci of CSR programs we can grasp their nature and expected outcomes. Additionally, this can illustrate the motives behind the adoption of those programs, and improve our understanding of the distribution of benefits. Given the global importance of CSR and sport-for-development programs, future research should extend this line of inquiry to a comprehensive population of sport organizations, which could allow for crosscontinent comparisons. A study of sport organizations in North America, Europe, and Asia 
would allow for an increased understanding of best practices and identification of opportunities for policy transfer across contexts. Future research should investigate the critical issues related to community development such as how sport organizations highly committed to social change differ from organizations with low commitment, and the process of decision making involved in these decisions. Furthermore, analyzing patterns of adoption of CSR practices among different sport settings and organizations could shed light into some of the challenges organizations face and the resources needed to overcome these challenges. Lastly, it would be worthwhile to explore in more depth the CSR pillars: labor relations, environmental management and sustainability, community relations, philanthropy, diversity and equity, and corporate governance (Babiak \& Wolfe, 2013).

To develop a broader research agenda looking at the relationship between CSR in sport and community development, it is imperative that the ideological drivers be explored from a pluralist perspective embracing varieties that manifest and evolve in the realm of sport. This can allow achieving a more realist understanding of CSR's nature as applied to sport. From this standpoint, we can examine the implications of CSR programs for the sustainable management of sport organizations and their ramifications to society. As such, CSR needs to be incorporated into the sport-for-development discourse in order to find the means for fostering the community value of CSR programs. Sport organizations viewed as community assets can be leveraged to obtain sustainable benefits (Sparvero \& Chalip, 2007). By extension, the CSR programs of sport organizations provide a potential added source of community value that can be leveraged for achieving sustainable community development. To this end, the building and implementation of partnerships between sport organizations and cities or regions merit further examination. Overall, we propose a community-based research agenda on the realm of strategic CSR in sport that can 
investigate its potential as a tool for sustainable development (Table 1). The focus is on both process and outcomes. Specifically, research is needed to examine the process of development of CSR initiatives, including the motivations, assets, and resources of all partners. Equally important is research examining community outcomes, including financial, social, and environmental performance metrics, as indicated by the triple-bottom-line.

[Table 1 to be inserted here]

As outlined in Table 1, we propose four research themes that each sets out a research proposition and particular research questions. The research themes discussed below are: (1) Strategic Alignment and Social Change; (2) Ideological Varieties; (3) Program Design and Stakeholder Engagement; and (4) Program Sustainability.

Strategic alignment and social change. Based on the emerging political role of CSR (Scherer \& Palazzo, 2011), it is postulated that by extension CSR in sport due to the unique features of sport (Smith \& Westerbeek, 2007) and strategic character (Babiak \& Wolfe 2009) can engender positive outcomes to local communities if it is aligned with community development strategies (Misener \& Mason, 2009) or even more broadly integrated with sport-for-development policies (Lyras \& Welty Peachey, 2011), and as such effectively leveraged (Sparvero \& Chalip, 2007). This line of thinking leads to the first two research propositions:

RP1. The strategic alignment of sport-related CSR and community sport-for- development planning can deliver social benefits to local areas.

RP2. Sport-related CSR can be leveraged to enable positive social change. 
Ideological varieties. As CSR is inextricably linked with neo-liberalism (Peck, 2010), it may turn away civic-minded community development actors who support the welfare state and have different political beliefs. To overcome this constraint, a pluralist and more encompassing view of the ideological varieties at play (Vallentin, 2012) in sport-related CSR is needed. CSR in sport viewed as a hybrid mode of strategy-making opens up possibilities for considering, debating and synthesizing the ideological varieties and worldviews that underlie beneath and can thereby enable the contextual embeddedness of sport-related CSR programs in terms of how they interact with other policies, systems and ways of thinking about community development. This mind set brings forward the third research proposition:

RP3. The ideological varieties in sport-related CSR represent different worldviews that need to be appreciated and synthesized.

Program design and stakeholder engagement. The multiplicity of some CSR programs raises the question of how effective they are. Although scholarship has indicated that sport related CSR initiatives have the potential to generate benefits such as increased ticket sales and fan loyalty along with improved brand image (Walker \& Kent, 2009), empirical research evaluating and directly measuring the long-term benefits is lacking. Having a systematic way of measuring the success of CSR programs would increase stakeholder accountability and facilitate the development of relational networks (Hamil \& Morrow, 2011). Engaging a wide range of stakeholders in the process of CSR design, implementation, and evaluation is essential for community development and achievement of the objectives set in the CSR initiatives. Having mutually beneficial partnerships increases the leveraging potential of CSR through sport (Walters \& Anagnostopoulos, 2012). Similarly, sport organizations viewed as community assets 
can be leveraged to obtain sustainable benefits (Sparvero \& Chalip, 2007). This line of thought brings the fourth and fifth research propositions:

RP4. The degree of success sport organizations and targeted community actors realize is dependent on the manner in which CSR programs are designed, implemented, and managed using effectively their attributes in conjunction with sport-community assets.

RP5. CSR activities provide opportunities to create new networks and transform existing networks among stakeholders.

Program sustainability. Sport-based programs focused on economic development, social inclusion, cultural cohesion and healthy lifestyles have increasingly received political and institutional support (Sherry, Schulenkorf, \& Chalip, 2015). To enhance the bottom line, CSR programs and socially responsible activities should be utilized (Cochran, 2007). The triplebottom-line of economic, social and environmental development (and the associated policies) impacts not only local communities, but countries as well. To achieve successful CSR programs in all three aspects, it is imperative to implement joint strategies (locally and globally) by involving a wide range of stakeholders. This brings forward the sixth research proposition:

RP6. The success of CSR programs should be evaluated in terms of impacts on the triple-bottomline.

In conclusion, sport, because of its popularity and universal nature, has the power to mobilize people and positively influence the lives of many around the world, including people that many others find it difficult to reach. Sport organizations are well positioned to influence society in general and communities in particular (Smith \& Westerbeek, 2007). For example, professional football is viewed as an ambassador for supporting the integration process of the European Union (Foster \& Pope, 2004). Over the years the European Union has established itself 
as the most active trading bloc promoting CSR (Diamantopoulou, 2005). Sport has the power to change society, and the CSR activities through which social change occurs have the potential to enhance the organization's performance and competitiveness (Breitbarth \& Harris, 2008). We believe that CSR activities within the sport industry are not a temporary phenomenon, but a reality, and the trend will be to not only have more sport organizations adopting such activities, but also for organizations to broaden the scope of existing activities due to the professionalization of sport, its high public profile and responsibilities to the community. 


\section{References}

Babiak, K. (2010). The role and relevance of corporate social responsibility in sport: A view from the top. Journal of Management and Organization, 16(4), 528-549.

Babiak, K., \& Trendafilova, S. (2011). CSR and environmental responsibility: Motives and pressures to adopt sustainable management practices. Corporate Social Responsibility and Environmental Management, 18(1), 11-24.

Babiak, K., \& Trendafilova, S. (2010). Corporate social responsibility in professional sport: Motives to be 'Green'. In Placido Rodriguez, Stefan Kesenne, \& Jaume Garcia (Eds.), Social Responsibility and Sustainability in Sports. Oviedo, Spain: Oviedo University Press.

Babiak, K., \& Wolfe, R. (2006). More than just a game? Corporate social responsibility and Super Bowl XL. Sport Marketing Quarterly, 15, 214-222.

Babiak, K., \& Wolfe, R. (2009). Determinants of corporate social responsibility in professional sport: Internal and external factors. Journal of Sport Management, 23(6), 717-742.

Babiak, K., \& Wolfe, R. (2013). Perspectives on social responsibility in sport. In J. L. ParamioSalcines, K. Babiak, \& G. Walters (Eds.), The Routledge Handbook of Sport and Corporate Social Responsibility (pp. 17-34). Abingdon: Routledge.

Babiak, K., Mills, B., Tainsky, S., \& Juravich, M. (2012). An investigation into professional athlete philanthropy: Why charity is part of the game. Journal of Sport Management, 26, 159-176.

Banda, D., \& Gultresa, I. (2015). Using Global South sport-for-development experiences to inform Global North CSR design and implementation: A case study of Euroleague Basketball's One Team programme. Corporate Governance, 15(2), 196-213. 
Banerjee, S. B. (2007). Corporate Social Responsibility - The Good, the Bad and the Ugly. Cornwall: Edward Elgar.

Beliveau, B., Cottrill, M., \& O Neill, H. M. (1994). Predicting corporate social responsiveness: A model drawn from three perspectives. Journal of Business Ethics, 13(9), 731-738.

Boas, T. C., \& Gans-Morse, J. (2009). Neoliberalism: From new liberal philosophy to anti-liberal slogan. Studies in Comparative International Development, 44, 137-161.

Bonini, S., Mendonca, L., \& Oppenheim, J. (2006). When social issues become strategic. The McKinsey Quarterly, 2, 20-31.

Breitbarth, T., \& Harris, P. (2008). The role of corporate social responsibility in the football business: Towards the development of a conceptual model. European Sport Management Quarterly, 8(2), 179-206.

Brenner, N., Peck, J., \& Theodore, N. (2010). Variegated neoliberalization: Geographies, modalities, pathways. Global Networks, 10(2), 182-222.

Brown, A. (2000). European football and the European Union: Governance, participation and social cohesion - towards a policy research agenda. Soccer and Society, 1(2), 129-150.

Business in the Community (2008). Community engagement: Insights into the contribution of European club football. London: Business in the Community/G14.

Campbell, J. L. (2007). Why would corporations behave in socially responsible ways? An institutional theory of corporate social responsibility. Academy of Management Review, 32(3), 946-967.

Cantelon, H., \& Letters, M. (2000). The making of the ICO environmental policy as the third dimension of the Olympic Movement. International Review for the Sociology of Sport, 35(3), 294-308. 
Carey, M., Mason, D. S., \& Misener, L. (2011). Social responsibility and the competitive bid process for major sporting events. Journal of Sport \& Social Issues, 35(3), 246-263.

Carroll, A. B. (1979). A three-dimensional model of corporate social performance. Academy of Management Review, 4, 497-505.

Carroll, A. B. (1991). The pyramid of corporate social responsibility: Toward the moral management of organizational stakeholders. Business Horizon, July-August, 39-48.

Carroll, A. B. (1999). Corporate social responsibility. Business and Society, 38(3), 268-295.

Casper, J., Pfahl, M., \& McSherry, M. (2012). Athletics department awareness and action regarding the environment: A study of NCAA athletics department sustainability practices. Journal of Sport Management, 26, 11-29.

Chalip, L. (2002). Using the Olympics to optimise tourism, Fundamental Olympic Lessons, Olympic Studies Centre, Universitat Autònoma de Barcelona (http://blues.uab.es/olympic.studies/dir/fl.html)

City of Arlington. (2004). Master agreement regarding Dallas Cowboys Complex Development Project. Retrieved from http:/www.arlingtontx.gov/citysecretary/ pdf/elections/110204/110204_MasterAgreement.pdf

Coady, L., Snider, S., Duffy, A., \& Legg, R. (2007). Corporate social responsibility for the Vancouver 2010 Olympic and Paralympic winter games: Adopting and adapting best Practices. Corporate Social Responsibility Review, Autumn, 11-15.

Coalter, F. (2013). Sport for development: What game are we playing? Abingdon: Routledge. Cochran, P. L. (2007). The evolution of corporate social responsibility. Business Horizons, $50(6), 449-454$ 
Crampton, W., \& Patten, D. (2008). Social responsiveness, profitability and catastrophic events: Evidence on the corporate philanthropic response to 9/11. Journal of Business Ethics, 81, 863-873.

Croci, O. (2009). Taking the field: The European Union and sport governance. In I. Tömmel \& A. Verdun (Eds.) Innovative governance in the European Union: The politics of multilevel policymaking (pp. 139-158). Boulder, CO: Lynne Rinner.

Dahlsrud, A. (2008). How Corporate Social Responsibility is defined: An analysis of 37 definitions. Corporate Social Responsibility and Environmental Management, 15, 1-13.

Diamantopoulou, A. (2005). Foreword. In A. Habisch, J. Jonker, M. Wegner, \& R. Schmidpeter (Eds.), Corporate social responsibility across Europe. Berlin, Germany: Springer.

Dowling, M., Robinson, L., \& Washington, M. (2013). Taking advantage of the London 2012 Olympic Games: corporate social responsibility through sport partnerships. European Sport Management Quarterly, 13(3), 269-292.

Essex, S., \& Chalkley, B. (2003). Urban transformation from hosting the Olympic Games: university lecture on the Olympics. Barcelona: Centre d'Estudis Olímpics. (http://olympicstudies.uab.es/lectures/web/pdf/essex.pdf).

Foster, J., \& Pope, N. K. L. (2004). The political economy of global sporting organisations. London: Routledge.

Frederick, W. C. (1986). Toward CSR3: Why ethical analysis is indispensable and unavoidable in corporate affairs. California Management Review, 28, 126-141.

Frederick, W. C. (1994). From CSR1 to CSR2: The maturing of business-and-society thought. Business \& Society, 33, 150-164. 
Garcia, B. (2009). Sport governance after the White Paper: The demise of the European model? International Journal of Sport Policy and Politics, 1(3), 267-284.

Gouldson, A. (2006). Do firms adopt lower standards in poorer areas? Corporate social responsibility and environmental justice in the EU and the US. Area, 38(4), 402-412.

Hamil, S., \& Morrow, S. (2011). Corporate social responsibility in the Scottish Premier League: Context and motivation. European Sport Management Quarterly, 11(2), 143-170.

Hanlon, G. (2008). Rethinking Corporate Social Responsibility and the role of the firm - On the denial of politics. In A. Crane et al. (Eds.), The Oxford Handbook of Corporate Social Responsibility (pp. 156-172). Oxford: Oxford University Press.

Harvey, D. (2005). A brief history of neoliberalism. Oxford: Oxford University Press.

Hayhurst, L. (2009). The power to shape policy: Charting sport for development and peace policy discourses. International Journal of Sport Policy and Politics, l(2), 203-227.

Henry, I. (2009). European models of sport: Governance, organizational change and sports policy in the EU. Hitotsubashi Journal of Arts and Sciences, 50, 41-52.

Hess, D., Rogovsky, N., \& Dunfee, T. W. (2002). The next wave of corporate community investment: Corporate social initiatives. California Management Review, 44, 110-125.

Hess, D., \& Warren, D. E. (2008). The meaning and meaningfulness of corporate social initiatives. Business and Society Review, 113(2), 163-197.

Hilgers, M. (2010). The three anthropological approaches to neoliberalism. International Social Science Journal, 61(202), 351-364.

Kihl, L. A., \& Tainsky, S. (2013). Delivery of large-scale CSR efforts through corporate community involvement: Lessons from Major League Baseball's Reviving Baseball in Inner 
Cities program. In J. L. Paramio-Salcines, K. Babiak, \& G. Walters (Eds.), The Routledge Handbook of Sport and Corporate Social Responsibility (pp.185-197). Abingdon: Routledge.

Kinderman, D. (2011). 'Free us up so we can be responsible!' The co-evolution of Corporate Social Responsibility and neo-liberalism in the UK, 1977-2010. Socio-Economic Review, 10, 29-57.

Kotler, P., \& Lee, N. (2005) Corporate social responsibility - Doing the most good for your company and your cause. New Jersey: John Wiley and Sons, Inc.

Kulczycki, W., \& Koenigstorfer, J. (2016). Doing good in the right place: City residents' evaluations of professional football teams' local (vs. distant) corporate social responsibility activities. European Sport Management Quarterly, In Press, DOI:10.1080/16184742.2016.1164736.

Levermore, R. (2010). CSR for development through sport: Examining the potential and limitations. Third World Quarterly, 31(2), 223-241.

Levermore, R., \& Beacom, A. (Eds.). (2009). Sport and international development. Basingstoke: Palgrave Macmillan.

Lyras, A., \& Welty Peachey, J. (2011). Integrating sport-for-development theory and praxis. Sport Management Review, 14(4), 311-326.

Margolis, J. D., \& Walsh, J. P. (2003). Misery loves companies: Rethinking social initiatives by business. Administrative Science Quarterly, 48(2), 268-305.

Marquis, C., Glynn, M. A., \& Davis, G. F. (2007). Community isomorphism and corporate social action. The Academy of Management Review, 32(3), 925-945. 
McWilliams, A., \& Siegel, D. (2000). Corporate social responsibility and financial performance: Correlation or misspecification? Strategic Management Journal, 21(5), 603-609.

Misener, L., \& Mason, D. S. (2009). Fostering community development through sporting events strategies: An examination of urban regime perceptions. Journal of Sport Management, 23, 770-794.

Misener, L., Sant, S. L., \& Mason. D. S. (2013). Engaging communities through sport: Sustainability as a means of enacting CSR. In J. L. Paramio-Salcines, K. Babiak, \& G. Walters (Eds.), The Routledge Handbook of Sport and Corporate Social Responsibility (pp.198-208). Abingdon: Routledge.

Mohr, L. A., Webb, D. J., \& Harris, K. E. (2001). Do consumers expect companies to be socially responsible? The impact of corporate social responsibility on buying behavior. Journal of Consumer Affairs, 35(1), 45-72.

NRDC. (2012) NRDC Report, Game Changer: How the sports industry is saving the $\begin{array}{llllll}\text { environment. } & \text { Retrieved } & \text { on } & \text { February } & \text { 23 }\end{array}$ http://www.nrdc.org/greenbusiness/guides/sports/ files/Game-Changer-report.pdf.

Orlitzky, M., Schmidt, F. L., \& Rynes, S. L. (2003). Corporate social and financial performance: A meta-analysis. Organization Studies, 24(3), 403-440.

Paramio-Salcines, J., L., Babiak, K., \& Walters, G. (Eds.). (2013). The Routledge Handbook of Sport and Corporate Social Responsibility. Abingdon: Routledge.

Peck, J. (2010). Constructions of neoliberal reason. Oxford: Oxford University Press. 
Pfahl, M. E. (2010). Strategic issues associated with the development of internal sustainability teams in sport and recreation organizations: A framework for action and sustainable environmental performance. International Journal of Sport Management Recreation and Tourism, 6, 37-61.

Pfahl, M. (2011). Sport and the natural environment: A strategic guide. Dubuque: IA, Kendall Hunt.

Pfahl, M., Casper, J., Trendafilova, S., McCullough, B., \& Nguyen, S. (2015). Crossing boundaries: An examination of sustainability department and athletics department collaboration regarding environmental issues. Communication and Sport, 3(1), 27-56.

Pfahl, M., \& Ott, M. (2010). Athletics departments and the environment: Environmental efforts revenue generation on your campus. Athletics Administration, 45, 16-19.

Porter, M. E., \& Kramer, M. R. (2006). Strategy and society: The link between competitive advantage and corporate social responsibility. Harvard Business Review, 84(12), 78-92.

Prieto-Carron, M., Lund-Thomsen, P., Chan, A., Muro, A., \& Bhushan, C. (2006). Critical perspectives on CSR and development: What we know, what we don't know, and what we need to know. International Affairs, 82, 977-987.

Ratten, V., \& Babiak, K. (2010). The role of social responsibility, philanthropy and entrepreneurship in the sport industry. Journal of Management \& Organization, 16(4), 482487.

Reich, R. B. (2007). Supercapitalism. USA: Alfred A. Knopf.

Scherer, A. G., \& Palazzo, G. (2011). The new political role of business in a globalized world: A review of a new perspective on CSR and its implications for the firm, governance, and democracy. Journal of Management Studies, 48(4), 899-931. 
Schulenkorf, N. (2012). Sustainable community development through sport and events: A conceptual framework for Sport-for-Development projects. Sport Management Review, 15(1), 1-12.

Schulenkorf, N., \& Adair, D. (Eds.). (2014). Global sport-for-development: Critical perspectives. Basingstoke: Palgrave Macmillan.

Shamir, R. (2008). The age of responsibilization: On market-embedded morality. Economy and Society, 37(1), 1-19.

Sherry, E., Schulenkorf, N., \& Chalip, L. (2015). Managing sport for social change: The state of play. Sport Management Review, 18(1), 1-5.

Sheth, H., \& Babiak, K. (2010). Beyond the game: Perceptions and priorities in corporate social responsibility in the sport industry. Journal of Business Ethics, 91(3), 433-450.

Siegele, L., \& Ward, H. (2007). Corporate social responsibility: A step towards stronger involvement of business in MEA implementation? RECIEL, 16(2), 135-144.

Skinner, J., Zakus, D. H., \& Cowell, J. (2008). Development through sport: Building social capital in disadvantaged communities. Sport Management Review, 11(3), 253-275.

Smith, A. C. T., \& Westerbeek, H. M. (2007). Sport as a vehicle for deploying corporate social responsibility. Journal of Corporate Citizenship, 25, 43-54.

Sparvero, E. S., \& Chalip, L. (2007). Professional teams as leverageable assets: Strategic creation of community value. Sport Management Review, 10(1), 1-30.

Sparvero, E. S., \& Kent, A. (2014). Sport team nonprofit organizations: Are sports doing well at “doing good?” Journal of Applied Sport Management, 4, 98-121. 
Sports Philanthropy Project. (2007). Sports Philanthropy Project Helps Teams and Athletes Partner With Community Groups to Promote Health and Well-Being. Report to Robert Wood Johnson Foundation.

Subhabrata, B. (2007). Corporate social responsibility. Northampton, MA : Edward Elgar Publishing Limited.

Swearingen White, S. (2009). Early participation in the American College and University Presidents' Climate Commitment. International Journal of Sustainability in Higher Education, 10(3), $215-227$.

Trendafilova, S., \& Nguyen, S. (2015). Corporate social responsibility and the environment in the sport industry. In J. Casper \& M. Pfahl (Eds.), Sport management and the natural environment: Theory and practice (pp.76-87). New York, NY: Routledge.

Trendafilova, S., Pfahl, M., \& Casper, J. (2013). CSR and environmental responsibility: The case of NCAA Athletic Departments (pp.105-118). In Juan Luis Paramio, Kathy Babiak, \& Geoff Walters (Eds.), The Routledge Handbook of Sport and Corporate Social Responsibility. Routledge, UK.

Vallentin, S. (2012). Neoliberalism and CSR: Overcoming Stereotypes and Embracing Ideological Variety. Paper presented at the 28th EGOS Colloquium in Helsinki, Finland, July 2-7, 2012 SWG 10: The Changing Role of Business in Global Society.

Vogel, D. (2005). The market for virtue. Washington, DC: Brookings Institution Press.

Waddock, S. (2004). Parallel universes: Companies, academics, and the progress of corporate citizenship. Business and Society Review, 109, 5-42. 
Walker, M., \& Kent, A. (2009). Do fans care? Assessing the influence of corporate social responsibility on consumer attitudes in the sport industry. Journal of Sport Management, 23(6), 743-769.

Walker, M., \& Parent, M. (2010). Toward an integrated framework of corporate social responsibility, responsiveness, and citizenship in sport. Sport Management Review, 13(3), 198-213.

Walters, G., \& Anagnostopoulos, C. (2012). Implementing corporate social responsibility through social partnerships. Business Ethics: A European Review, 21(4), 417-433. 


\begin{tabular}{|c|c|c|}
\hline Research Themes & Research Propositions & Research Questions \\
\hline \multirow[t]{2}{*}{$\begin{array}{l}\text { Strategic Alignment and Social } \\
\text { Change }\end{array}$} & $\begin{array}{l}\text { RP1. The strategic alignment } \\
\text { of sport-related CSR and } \\
\text { community sport-for- } \\
\text { development planning can } \\
\text { deliver social benefits to local } \\
\text { areas. }\end{array}$ & $\begin{array}{l}\text { 1. What values should underpin the } \\
\text { strategic alignment of sport-related } \\
\text { CSR and community sport } \\
\text { development planning? } \\
\text { 2. How can social capital be fostered } \\
\text { through sport-related CSR? } \\
\text { 3. How can active citizenship be } \\
\text { promoted through sport-related } \\
\text { CSR? }\end{array}$ \\
\hline & $\begin{array}{l}\text { RP2. Sport-related CSR can } \\
\text { be leveraged to enable } \\
\text { positive social change. }\end{array}$ & $\begin{array}{l}\text { 1. What are the best means to } \\
\text { leverage sport-related CSR for } \\
\text { achieving positive social change? } \\
\text { 2. How can sport organizations and } \\
\text { local communities coordinate the } \\
\text { implementation of sport-related CSR } \\
\text { strategies? }\end{array}$ \\
\hline Ideological Varieties & $\begin{array}{l}\text { RP3. The ideological varieties } \\
\text { in sport-related CSR } \\
\text { represent different } \\
\text { worldviews that need to be } \\
\text { appreciated and synthesized. }\end{array}$ & $\begin{array}{l}\text { 1. What are the ideological varieties } \\
\text { in sport-related CSR and what } \\
\text { worldviews do they represent? } \\
\text { 2. How can the ideological varieties } \\
\text { in sport-related CSR be synthesized } \\
\text { to facilitate inclusiveness? }\end{array}$ \\
\hline \multirow[t]{2}{*}{$\begin{array}{l}\text { Program Design and Stakeholder } \\
\text { Engagement }\end{array}$} & $\begin{array}{l}\text { RP4. The degree of success } \\
\text { sport organizations and } \\
\text { targeted community actors } \\
\text { realize is dependent on the } \\
\text { manner in which CSR } \\
\text { programs are designed, } \\
\text { implemented, and managed } \\
\text { using effectively their } \\
\text { attributes in conjunction with } \\
\text { sport-community assets. }\end{array}$ & $\begin{array}{l}\text { 1. What combination of sport-related } \\
\text { CSR attributes can more effectively } \\
\text { achieve community development? } \\
\text { 2. What unique assets do sport } \\
\text { organizations possess and how can } \\
\text { they be leveraged to optimize CSR } \\
\text { efforts? }\end{array}$ \\
\hline & $\begin{array}{l}\text { RP5. CSR activities provide } \\
\text { opportunities to create new }\end{array}$ & $\begin{array}{l}\text { 1. How does the development and } \\
\text { implementation of CSR activities }\end{array}$ \\
\hline
\end{tabular}




\begin{tabular}{|l|l|l|}
\hline & $\begin{array}{l}\text { networks and transform } \\
\text { existing networks among } \\
\text { stakeholders. }\end{array}$ & $\begin{array}{l}\text { affect networks? } \\
\text { 2. What are the most effective } \\
\text { patterns of interaction among } \\
\text { stakeholders in developing and } \\
\text { managing CSR programs? }\end{array}$ \\
\hline Program Sustainability & $\begin{array}{l}\text { RP6. The success of CSR } \\
\text { programs should be evaluated } \\
\text { in terms of impacts on the } \\
\text { triple-bottom-line. }\end{array}$ & $\begin{array}{l}\text { 1. To what extent do CSR programs } \\
\text { impact financial performance (e.g., } \\
\text { shareholder value, profitability, } \\
\text { consumer purchase intentions)? }\end{array}$ \\
2. To what extent and through what \\
mechanisms do CSR programs \\
impact environmental sustainability? \\
3. To what extent do CSR programs \\
impact social performance (e.g., \\
diversity, health and safety, \\
community)?
\end{tabular}

Table 1: A Community Development Research Agenda for CSR in Sport 